\title{
New Media: Technological Design of Forms and Boundaries of Cultural Experience
}

\author{
Dmitry V. Galkin* \\ National Research Tomsk State University \\ 30 Lenin Str., Tomsk, 634050, Russia
}

Received 30.03.2015, received in revised form 19.05.2015, accepted 05.06.2015

The article is concerned with the problem of the new media definition as a phenomenon of modern digital culture. The author proceeds from the fact that media novelty, from the standpoint of culture history, is related to the question of experience boundaries (printing was the new media for medieval era and photography - for the printing culture of the 20th century). The new media of digital culture can be divided on the principle of the boundaries that they change: domestic (change the boundaries of private life), homeless (the boundaries of public space) and intimate (the boundaries of human body).

Keywords: new media, digital culture, cultural outlook, boundaries of experience.

DOI: 10.17516/1997-1370-2015-8-8-1541-1550.

Research area: culture studies, philosophy, art history.

A few years ago in California Silicon valley such a half-joke - half-truths was popular. Someone counted that the power of a smartphone - at that period of time it was IPhone 4 - is roughly equal to all of the computing power that was used by NASA for training flight to the Moon. There was a humorous comparison: in 1960 we launched a man to the Moon, and today we are launching birds into pigs (of course, there is a view of the famous game "Angry Birds" (by Finnish company Rovio). This idea of technology development at all their exponentially growing perfection interestingly stays within the theoretical framework of the dialogue of technological and cultural determinism.

Cultural determinism combines discourses in which technologies are socialized, interpreted and adapted by various groups, and then transformed into products and specific formats and practices of their use. Technological determinism is different, compensation logic, which was perfectly exemplified by M. McLuhan by the spread of printing (printing technology led to the emergence of national languages and states) (McLuhan, 2003), and G. Simondon linked it with inventors and engineers (as engineer does not invent anything, but simply reveals the potential that presents in the process of technological machine development) (Simondon, 1958). Both approaches end in inevitable deadlock and seem to be critically insoluble relative to each other. However, the most interesting begins at the moment when we try to grasp, understand and catch up the dialogue of these discourses. Of

(C) Siberian Federal University. All rights reserved

* Corresponding author E-mail address: gdv_t@mail.ru 
course, as theorists, historians and interpreters, we are always at the position of cultural determinism and here there is no escape, we are not engineers. We can take the position of liberal businessmen, transhumanists or the position of the Orthodox reactionaries. In this case I am more interested in the position of theoretical dialogue within the ontological theater - an interesting philosophical approach, which was proposed by the British theorist E. Pickering (he, in turn, is based upon the ideas of cybernetics). Why theater? It seems to me that Pickering, thus, tends to emphasize the element of surprise, the new that occurs in the clash of discourses and technologies, the openness in which we participate, but we understand that the result is unknown.

\section{New Media: Nothing New?}

So what is traditionally referred to the new media? Internet, social networks, digital photos, blogs, video games and e-book - it is a look from the 1990s, when everyone started talking about the new media. What is their novelty? In fact, for example, that they are interactive - you can leave comments, reply to a letter and "like". But aren't the old media - newspapers, for example, interactive? Citizens' letters to the newspaper "Pravda" is quite an interactive process that, at its time, led to very important social consequences. If interactivity lies in the ability of any person easily produce and distribute digital content, then the long-standing practice of documents copying and "samizdat" should remind that all this took place somewhere. Or another story. Ralph Baeran American engineer, the inventor of interactive television and home video game devices, who patented a lot of interesting developments that subsequently became game consoles.

In fact, it is difficult to say that the novelty of the new media is connected with interactivity, or, for example, with the use of hypertext. The first "hypertext browser" (or its prototype), is found the 16th century. It is "Book wheel" by Agnostino Ramelli - equipment of libraries and monasteries, common in those days. The idea of this wheel was that with the use of a single device
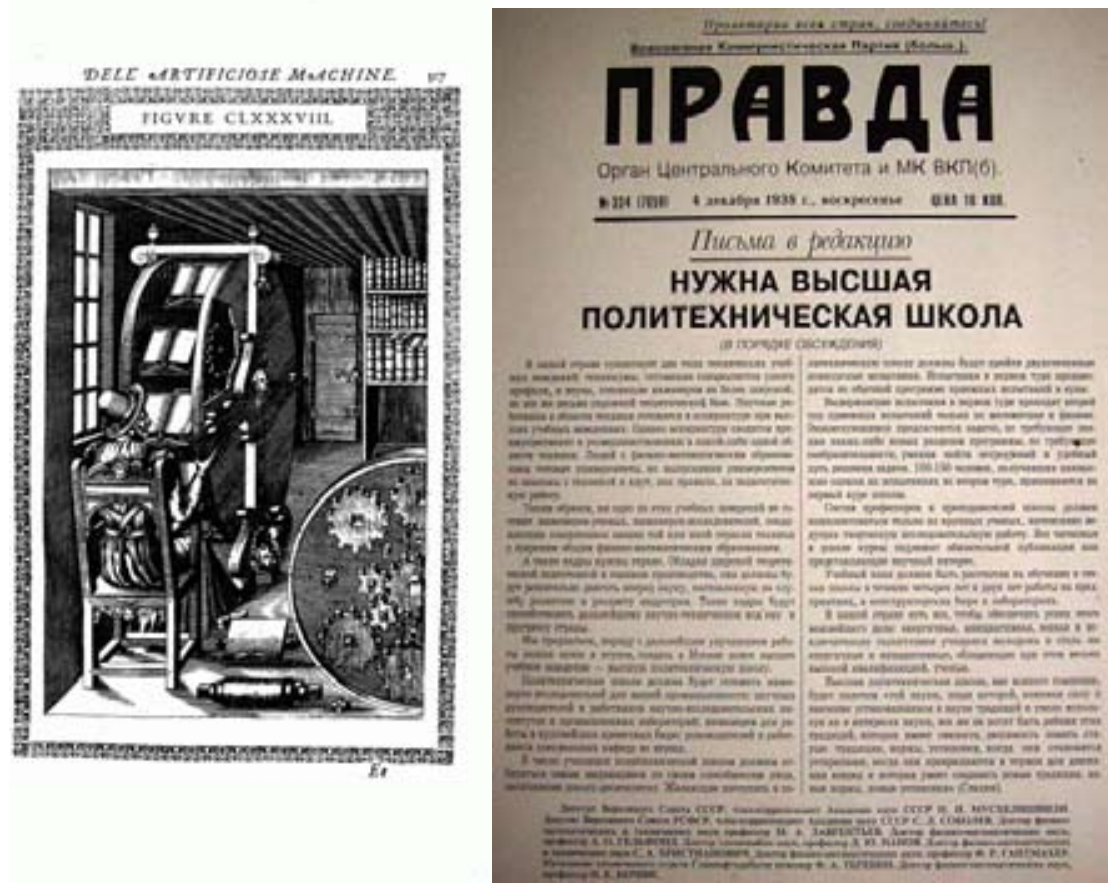
to provide maximum easy and fast access to the related text fragments from different books. Conceptually and technically primitive, the idea was implemented long before Ted Nelson, Tim Berners-Lee and other engineers technologized hypertext in the format that is used in the form of links to the Internet.

Perhaps novelty of the new media is in their hybridity? That is, when I have video and audio, animation, texts and chats at a Web page in one document? And all the hybrid content is hypertextually connected! But here, there is a difficulty with novelty again, because if we read McLuhan carefully, any media, by definition, is hybrid. So, what in this case allows us to talk about the new media? The possibility of communication in real time? And here, there is a difficulty again: radio (if we reckon it as the old media) worked in real-time long ago, having come to this, as well as television, even before the new media. Or, maybe, the novelty is in modularity, when we "upload" this, that and the other from the database to a hybrid structure and change fragments (here I have to refer to the authority of L. Manovich (Manovich, 2001)? It is not an entirely convincing argument. This principle was used not only in book publishing industry of the Renaissance, but had already been represented in the design and "page layout" of the Egyptian "Book of the Dead".

Well, then, perhaps, if we refer to the specific formats, maybe we can find something new and new media in them? For example, blogs. I think that famous German preacher Martin Luther and his incomparable "posts" on the church doors that changed European culture can be considered as the first blogger. In general, there is an unambiguous question of formats as well.

And when we abandon the role of "captain obvious" and thoroughly ask the question about the new media, as it seems to me, we face an even more important issue - the issue of boundaries.
The boundaries that are associated not so much with the media themselves, but with the conditions and spaces in which we exist using them. The boundaries of physical space and time, limits, associated with our body, with the urban space and social boundaries of the private and the public. A perfect example of such a question formulation is the discourse of the Internet of Things. The novelty of the new media is that they come out from the screen - pages, a monitor or a TV set, and as if sprawl into things. Another example is the archeology of media. The historical and cultural theory demonstrating that the new media have fundamentals that go beyond screen visualization and form semantic and axiological environment. And, of course, we can not but mention Actor-network theory (ANT) which insists that technical objects have an independent activity that is related not only to their use. Is this presentation shown on the screen by a lecturer or by a computer with a projector? Was it I who broke the window or a stone that broke it? If we think about it carefully, it was the stone that broke the window, wasn't it, not I? Consequently, the action of breaking is possible when there is a relationship of actors who commit it.

Let us look at the new media in terms of the issue of boundaries, dividing it into three categories according to the principle of what boundaries they extend.

\section{Domestic Media}

Let us suppose that we refer such interesting gadgets as IRobot - the popular robot vacuum cleaner, which creates a map of your apartment, vacuums and tidies to the new media. Or some of the trivial everyday new media: smart TV, game consoles, etc. These gizmos expand the boundaries of home space due to media structure: due to mobility, due to hybridization of physical and virtual space, due to changing the mode of time, which becomes different (before I ran to 


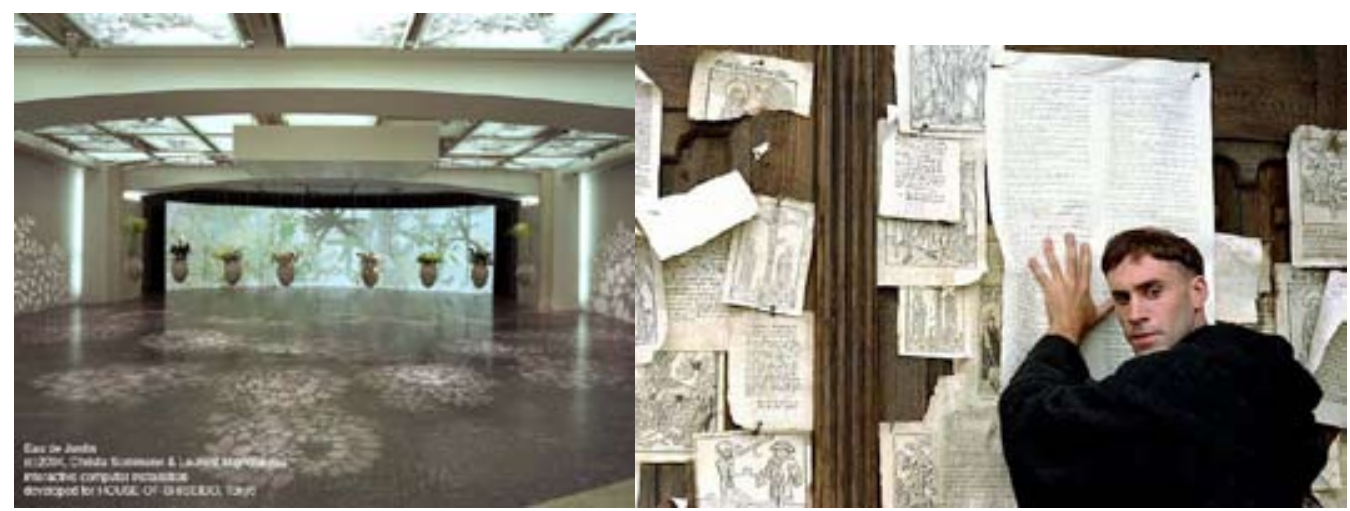

watch television on the program, and now I can record and watch it when I like it).

Smart home is an even more interesting option. Quite rapidly developing business. For example, imagine that a video surveillance system is connected to a database of local nondepartmental security forces and at once, seeing a guest' face "checks" the data of a person who came to see you. Or, for example, such an interesting function as a three-dimensional visualization of what you read. That is, if you upload the book connected to virtual reality, it visualizes what happens in the book to you in your bedroom. This is a variant of the domestic new media that embroider and enrich your experience by expanding the boundaries of semantic, physical and psychological (perception). Do not forget the bathroom, where the toilet is connected to the doctor's computer that allows controlling your tests and intelligent expert system analyzes and compares with other diagnoses and patients how your metabolism is going.

Someone might be interested in interior design by Austrian artists C. Sommerer and L. Mignonneau who work on the verge of design and contemporary art. They have an amazing multimedia - hybrid project when the objects in your interior (in this case it is a vase of flowers) and flowers serve as an interface from which graphic images emerge around - on the floor, on the walls and on a special screen. Images as if grow from the interaction with these flowers. I think it is an underrated interior technology, judging by how it is used in museums or business spaces.

I hope that our dear reader still remembers the anecdote about "Angry birds", written in the beginning? Here, there is another anecdotal story, which tells of a rather different but much related new media - domestic and intimate. This is the story of how a "smart" toilet was hacked by "hackers" and it started to shout and curse, pour water and flip toilet seat... So what? Big deal, just naughtiness! That maybe so if all this was not happening at the very moment when we were very vulnerable, and the situation itself became stupid, ridiculous and dangerous. In this sense the anecdote becomes a revelation of how the new media intrude not only on home but also on my personal intimate space.

With less humor and more critical irony British critical designers James Auger and Jimmy Loizeau follow this topic in the project "Carnivorous Domestic Entertainment Robots". These robots are very utilitarian and able to produce electricity as home bioelectrostations. For example, a watch, equipped with adhesive tape, on which insects fall, and bioelectric generator, absorbing flies, produces energy to show time. There is a similar floor lamp. Yet there is a table that eats mice and also produces light. 
The conception itself is very interesting - the new media, which are integrated into bioecosystem as carnivorous agents. They are not just screens or mechanisms - they "live" along with what lives in the house and eat as if they were carnivorous.

\section{"Homeless" Media}

In contrast to domestic media, homeless media are such new media, which are outside our usual domestic space and in which the boundaries of the urban environment are transformed by the media elements integration. Let us begin with the so-called media facades. This is, on my opinion, a wonderful project of the Museum of Modern Art in Austria. The most part of the building facade is turned into the screen, becoming a media facade in which urban space is connected with information space. Nowadays it is one of the most fascinating topics in the modern architecture - in which configuration you can combine the new media, and that we can get in the urban space?
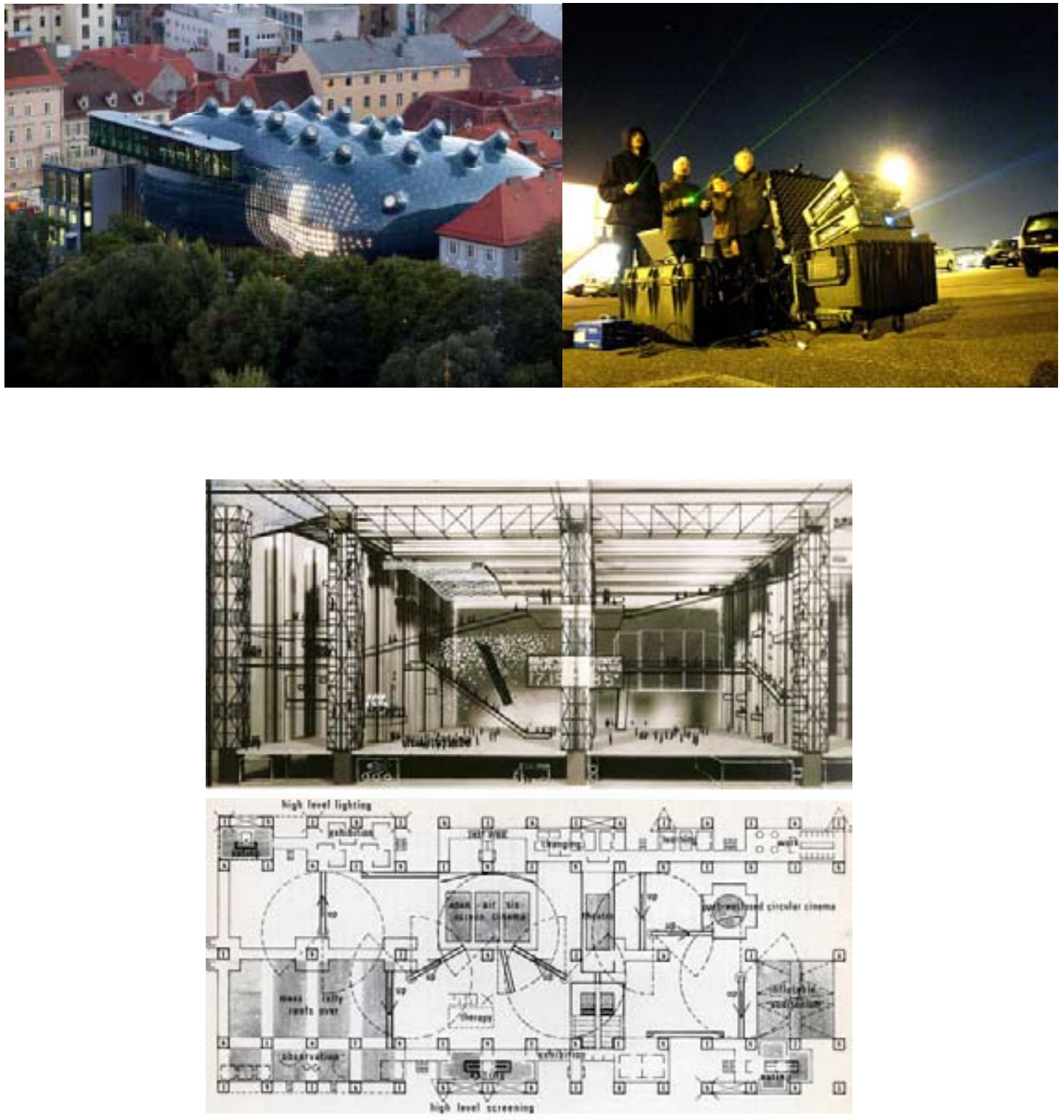


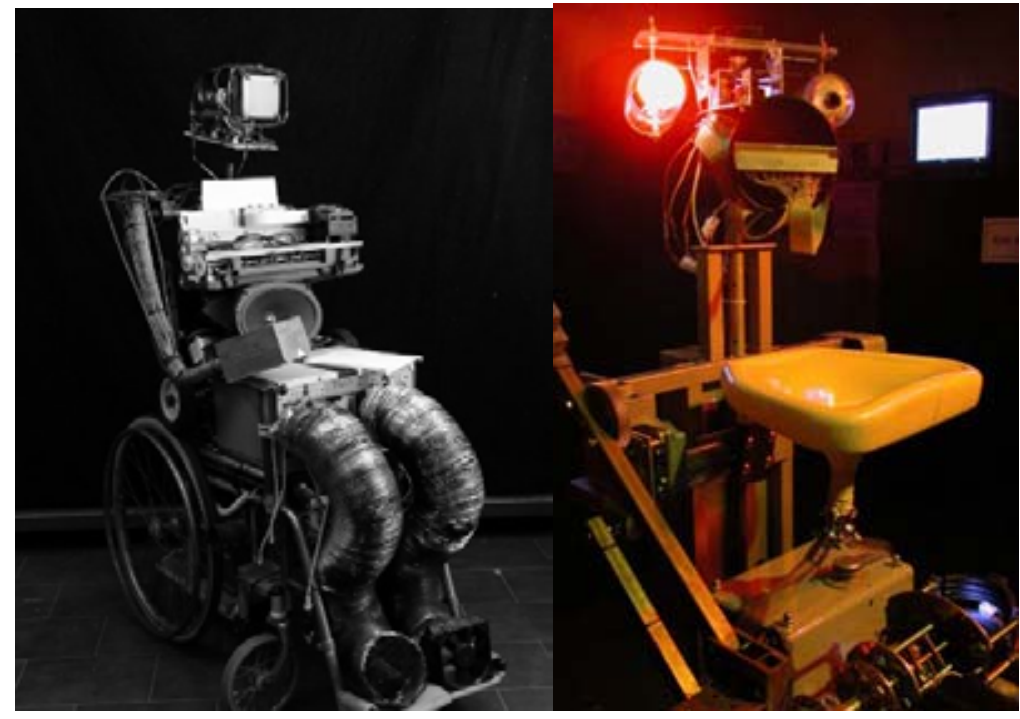

On the other hand, media activists demonstrate an alternative approach. In 2007, I met the New York group of the Graffiti Research Lab. They used the technology of projection drawing on the city walls with the help of LCDprojection and laser pointer. The projector creates a screen on any wall, and you can write and draw anything. They positioned it as a free format of expression in the urban space. I.e. the new media are making a transition from home and office use to the public space. The Graffiti Research Lab at the time got the first prize for this project at the Ars Electronica festival.

Let us refer to the conceptually more complex projects from the 1960-70s by the pioneers of interactive architecture Gordon Pask and Cedric Price. In their projects screen visualization on facade plays not the most important role. The main thing is the ability of automatic adaptive reconfiguration of space depending on how the needs of those who came there change: the ability to transform size, functionality, and other parameters. Price and Pask worked long enough over the project of "Fun Palace" (1961). It was not implemented, as well as the second project "Generator"
(1978). The principle was the same - the space that is interactively connected to those who are in this space, and the data that may be necessary, dynamically change in the course. Conceptual and technical solutions of these projects were partially implemented in the Pompidou Center, built under the influence of Price's ideas.

Here is an example of how space is formed in the entertainment industry. It is an expanding screen that was created for the concerts of the famous Irish rock band U2. In all the stories that exist around this project and other projects by Hoberman Bureau, there is also an idea of interactive architecture, data display and modification of space by turning screen into the physical space, mixing the physical space and onscreen effects.

As the attentive reader has probably already noticed, robots confidently get to the category of the new media. It is interesting that one of these homeless robots is implemented by one of the leaders of the Internet industry Google. It is an impressive car - robot. One of the convincing trends that is implemented in this new media car is a direct connection of driving and 


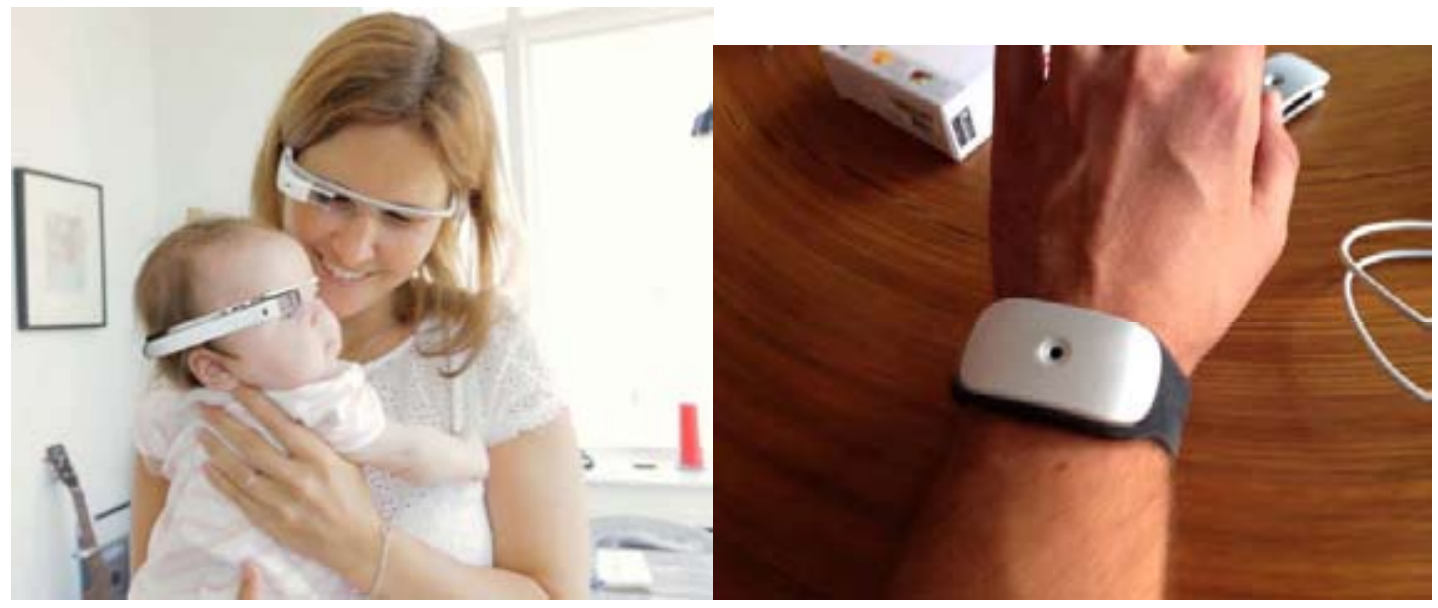

various communication functions, including the Internet and satellite navigation, as well as functions of artificial intelligence (including object recognition, traffic jams analysis, route planning, etc.). The car-robot even in the first test tours with a totally blind driver demonstrates the possibility of expanding the boundaries of mobility, including autonomous mobility of the vehicle itself.

Robotic technologies of the contemporary art lead to the similar conclusions. For example, Spanish techno artist Carlos Corpa and his robot $\mathrm{PaCo}$ - a poet beggar (Evolution Haute Couture ..., 2009). The robot uploads a dictionary from the Internet and begs, offering to compose a verse instead. Gapers throw it some coins, and the robot beggar reads the verses "with expression" and prints them out at once.

Of course, this story brings us back to the question of the trivialization of technology, as well as the following example. The drinking pal robot BarBot begs and drinks with you at a bar. You buy what he would like to drink (alcohol, of course!), and pour it down his sink. It gets drunk and starts to keep a meaningful conversation going with you, expanding, apparently, the boundaries and possibilities of social interaction.

\section{Intimate Media}

The subject of technology triviality gradually brings us to the issue of the most intimate boundaries of our existence - intimate boundaries of our body. And here we can not but avoid the developments from the world of sex industry. This new media object for intimate pleasures was presented at the specialized exhibition in Las Vegas. A high-tech doll has serious possibilities; for example, endlessly talk with the owner about his/her interests. And to understand the owner's character and hobbies, it studies you, including social networks on the Internet. It has a function of voice recognition and speech generator, it can keep a conversation going with you and still keep it to implement different variants of personality: it can be as cold as Farah or Wendy Wild. For an enthusiast and a lover, as they say.

Thus, intimacy is naturally connected to the fact of how the new media penetrate into our body from the screens, contact with us physically - the so-called wearable gadgets or wearables. Today, few people realize what boundaries expansion in this field promise. Here it is impossible not to mention the revolutionary device from the same developer Google - glasses Google Glass. If I am not entirely the master of my sight, this is the first sign that the intimacy of what I see and I want to 


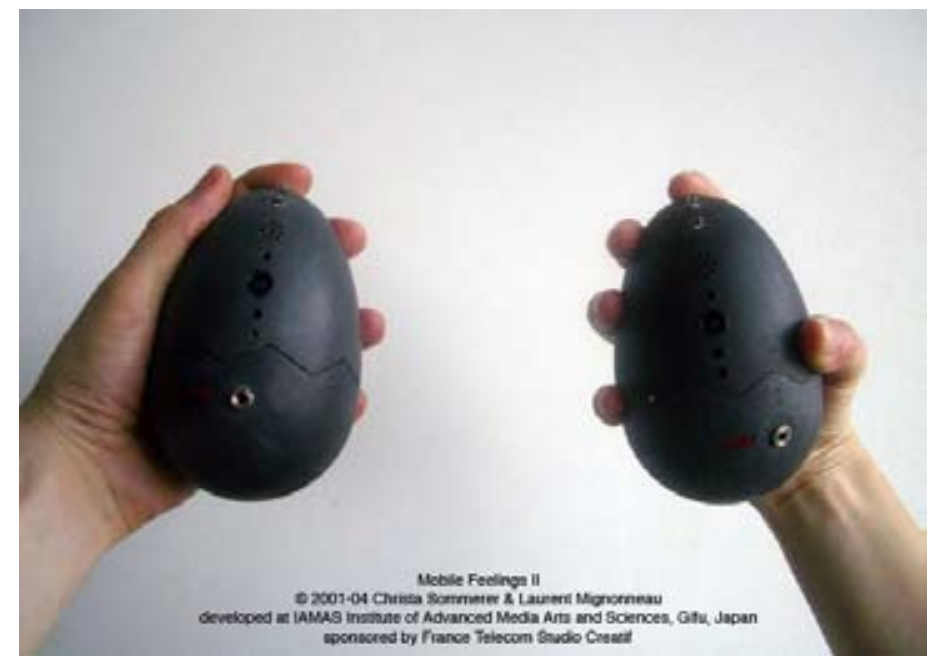

see, the intimacy of my desires that present in this sight, as if disengage with me, turning into digital video documentation. It exists in the form of the data that is uploaded and stored somewhere.

The combination of intimacy with the element of homelessness is represented in the project by L. Beloff (Evolution Haute Couture ..., 2013). In the spirit of the Internet of Things, she connects her shoes - high boots, to the network, high boots that allow you not to stay at home in front of screen in your computer bunker, chatting with friends, help you to talk on the move. The high boots all by themselves "go" online, connect to "Wi-Fi" and help you to communicate, while enjoying your physical presence somewhere on a walk.

In the project of wearable devices, where my good friend is enthusiastically engaged with, an example of the intimacy of the new media seems very interesting to me. It is called Healbe and represents an electronic bracelet, which must be worn permanently, and it checks your metabolism through skin, counts calories, processing data on a server and displaying it in your smartphone (or profile on your social network), evaluates, for example, the state of your diet, whether you are losing weight or getting fatter, and whether you follow the right regimen. The conception is that that in the future this device might be able to replace your dietician or personal trainer, tracking your parameters and sending you the following messages: "Hey, buddy, stop eating, because tomorrow you will gain X kilograms" or "Stop your workout because your heart is in a such state that nothing can help you - you are not losing weight, and your heart will only get worse".

And again, we will turn to the artists. I like this project very much. It is called "Mobile Feelings". These two egg-shaped devices in the hands of two people send heartbeat. Holding this device, you can feel the heartbeat of another person who holds the same device. Thus, you feel the heartbeats of each other and get a very unusual psychological experience of empathy and closeness. You start perceiving it all very emotionally, understanding that as if you have someone else's heart in your hands. It results into the effect of such an intimate and close contact, overcoming the usual boundaries of communication with its hypocrisy and social distance.

There is an art project which we can not but mention. It is a version of intimacy, which 
is integrated into our flesh - just under the skin. The "third ear" project by Australian artist Stelarc is characterized by him as "alternative architecture of body" (Evolution Haute Couture ..., 2009). His ear, implanted in his forearm, is not just an implant or prosthesis; his ear should become a universal commutator - media excess in a limited body. The artist has plans to make the ear a receiver and transmitter of data via Bluetooth and in this way connect to cyberspace through body. Stelarc offers an additional interface for a person who lives surrounded by technology - quite a trivial and extreme version of the intimate media.
In conclusion, let me return to the thesis of overcoming boundaries and establishment of the new media. We came to the conclusion that the new media is a category of formation and boundaries changes. We can not talk about the new media, as about something stable, in isolation from the social contexts, the boundaries of which the new media overcome. It is a strange flowing form. And the most interesting thing about the new media is how they form new configurations of the private/ public, urban and information space, virtual/real, screen/physical, body, life and death. And what I wanted to show demonstrates us the strength of the potential the new media technology contains.

\section{References}

1. Manovich L. The Language of New Media. Cambridge: MIT Press, 2001.

2. Pickering A. The Mangle of Practice: Time, Agency and Science. Chicago: University of Chicago Press, 1995.

3. Pickering A. The Cybernetic Brain: Sketches of Another Future. University of Chicago Press, 2010.

4. Simondon G. Du mode d'existence des objets techniques. Paris: Aubier, Editions Montaigne, 1958.

5. McLuhan M. O ponimanii media: esse o prodolzhenii cheloveka [Understanding Media: The Extensions of Man]. M.: Zhukovsky: 'KANON-press-Ts', 'Kuchkovo Pole', 2003.

6. McLuhan M. Galaktika Guttenberga. Sotvorenie cheloveka pechatnoi kul'tury [The Gutenberg Galaxy: The Making of Typographic Man]. Kyiv: "Nika-Tsentar", 2003.

7. Evolutsiia ot kutiur: Isskustvo i nauka v epokhu postbiologii [Evolution Haute Couture: Art and Science in the Post-Biological Age]. Part 1: Practice / Edited and curated by Dmitry Bulatov, book + 2 DVD-ROMs. Films Collection. Kaliningrad: BB NCCA, 2009.

8. Evolutsiia ot kutiur: Isskustvo i nauka v epokhu postbiologii [Evolution Haute Couture: Art and Science in the Post-Biological Age]. Part 2: Theory / Edited and curated by Dmitry Bulatov. Kaliningrad: BB NCCA, 2013. 


\title{
New media:
}

\section{технологическое конструирование форм \\ и границ культурного опыта}

\author{
Д.В. Галкин \\ Национальный исследовательский \\ Томский государственный университет \\ Россия, 634050, Томск, пр. Ленина, 30
}

Статья посвящена проблеме определения nеw теdia (новых медиа) как феномена современной циифровой культуры. Автор исходит из того, что новизна медиа с точки зрения истории культуры связана с вопросом о границах опыта (печать - новый медиум для Средневековья, фотография - для печатной культуры ХІХ века). Новые медиа циффровой культуры можно разделить по признаку тех границ, которые они изменяют: домашние (меняют границь частной жизни), бездомные (границьы публичного пространства) и интимные (границьь человеческого тела).

Ключевые слова: пеw теdia (новые медиа), цифрровая культура, культурная динамика, границы onbima.

Научная спещиальность: 24.00.00 - культурология, 09.00.00 - философские науки, 17.00.00 искусствоведение. 